\title{
Alternative control of post-harvest diseases in Tainung 1 papaya ${ }^{1}$
}

\author{
Andréa Mirne de Macêdo Dantas², Selma Rogéria de Carvalho Nascimento², Beatriz Letícia Silva da Cruz², \\ Fernando Henrique Alves da Silva², Márcia Michelle de Queiroz Ambrósio², Rosemberg Ferreira Senhor ${ }^{3}$
}

\section{ABSTRACT}

Controlling post-harvest papaya diseases without using agrochemicals is a challenge for producers. This study aimed at evaluating the effect of clove essential oil, biological fungicide $\left(\right.$ Trichodermil $\left.^{\circledR}\right)$, resistance inducer $\left(\mathrm{Cob}\right.$ Sistem $\left.{ }^{\circledR}\right)$ and chemical fungicide (Imazacure ${ }^{\circledR}$ ) on the in vitro control of phytopathogenic fungi isolates from papaya as well as on the post-harvest quality of Tainung 1 papaya. The in vitro experiment was conducted in a complete randomized design, with five fungal species $\mathrm{x}$ five treatments and five replications. The in vivo experiment was conducted in a complete randomized design, with five treatments $\mathrm{x}$ five storage times, five replications and three fruits per replication. The fruits were stored under refrigeration at $10 \pm 2{ }^{\circ} \mathrm{C}$ and $90 \pm 5 \%$ of relative humidity and evaluated at $0,7,14,21$ and 28 days of storage, plus two shelf life days at $25 \pm 2{ }^{\circ} \mathrm{C}$, to simulate marketing conditions. The inhibition of mycelial growth was evaluated in the in vitro experiment, while the diseases occurrence and post-harvest quality of the fruits were evaluated in the in vivo experiment. The clove essential oil and Trichodermil ${ }^{\circledR}$ were as efficient as Imazacure ${ }^{\circledR}$ in inhibiting the mycelial growth of Alternaria sp., Colletotrichum gloeosporioides and Rhizopus sp. The treatments with clove essential oil, Trichodermil ${ }^{\circledR}$ and Imazacure $^{\circledR}$ were similar in controlling the pathogens up to 21 days of storage. The treatments had no effect on the fruits soluble solid contents.

KEYWORDS: Carica papaya L.; Syzygium aromaticum; Trichoderma harzianum; copper phosphite.

\section{INTRODUCTION}

Brazil is the second world largest producer of papaya (Carica papaya L.) fruits, being the production of the country 1,424,650 tons, in 2016 (FAO 2016).

Anthracnose, peduncle rot and alternaria fruit spot are among the main post-harvest diseases that cause losses in the marketing of this fruit (Rezende \& Fancelli 1997, Suárez-Quiroz et al. 2013). The use of

\section{RESUMO}

Controle alternativo de doenças pós-colheita em mamão Tainung 1

O manejo de doenças pós-colheita de mamão sem o uso de agrotóxicos é um desafio para os produtores. Objetivou-se avaliar o efeito do óleo essencial de cravo-da-índia, do fungicida biológico Trichodermil ${ }^{\circledR}$, do indutor de resistência Cob Sistem ${ }^{\circledR}$ e do fungicida químico Imazacure $^{\circledR}$, no controle in vitro de fungos fitopatogênicos isolados de mamão e na qualidade pós-colheita de mamão Tainung 1 . O experimento in vitro foi conduzido em delineamento inteiramente casualizado, com 5 fungos x 5 tratamentos e cinco repetições. No experimento in vivo, utilizou-se delineamento inteiramente casualizado, com 5 tratamentos x 5 tempos de armazenamento, cinco repetições e três frutos por repetição. Os frutos foram armazenados sob refrigeração a $10 \pm 2{ }^{\circ} \mathrm{C}$ e $90 \pm 5 \%$ de umidade relativa e avaliados nos tempos $0,7,14,21$ e 28 dias, mais dois dias de tempo de prateleira a $25 \pm 2{ }^{\circ} \mathrm{C}$, para simular condições de comercialização. Avaliou-se a inibição do crescimento micelial para o experimento in vitro e, para o in vivo, a ocorrência de doenças e a qualidade pós-colheita dos frutos. O óleo essencial de cravo-daíndia e Trichodermil ${ }^{\circledR}$ foram tão eficientes quanto o Imazacure ${ }^{\circledR}$ na inibição do crescimento micelial de Alternaria sp., Colletotrichum gloeosporioides e Rhizopus sp. Até 21 dias de armazenamento, os tratamentos com cravo-da-índia, Trichodermil ${ }^{\circledR}$ e Imazacure ${ }^{\circledR}$ foram iguais, quanto ao controle de patógenos. Os tratamentos não propiciaram diferença quanto aos sólidos solúveis dos frutos.

PALAVRAS-CHAVE: Carica papaya L.; Syzygium aromaticum; Trichoderma harzianum; fosfito de cobre.

chemical products is the most common method for controlling diseases in papaya. However, products registered for this crop are not very efficient, and consumers are increasingly worried about problems related to the continuous and intensive use of agrochemicals in fruit species (Dantas et al. 2004, Suárez-Quiroz et al. 2013).

Thus, alternatives that are efficient, viable and cause less environmental impacts and risks to human

1. Manuscript received in Dec./2017 and accepted for publication in Mar./2018 (http://dx.doi.org/10.1590/1983-40632018v4850938).

2. Universidade Federal Rural do Semiárido, Mossoró, RN, Brasil.E-mails: andreamirne@gmail.com, selma@ufersa.edu.br, beatrizleticia@live.com, fernandosilvasr@hotmail.com,marciamichelle@ufersa.edu.br.

3. Fazenda Agrícola Famosa, Mossoró, RN, Brasil._E-mail: berg_fit@gmail.com. 
health are intensively studied. Some products based on agents used for biological control, plant essential oils and resistance inductors have been efficient for controlling diseases in various pathosystems, including fruit plants such as papaya. These products have no deleterious effects as chemical pesticides (Combrinck et al. 2011, Catão et al. 2013, HaminiKadar et al. 2014, Lubaina \& Murugan 2015, Valenzuela et al. 2015).

This study aimed at evaluating the effect of clove [Syzygium aromaticum (L.) Merrill and Perry] essential oil, biological fungicide $\left(\right.$ Trichodermil $\left.{ }^{\circledR}\right)$, resistance inducer $\left(\mathrm{Cob}\right.$ Sistem $\left.^{\circledR}\right)$ and chemical fungicide (Imazacure ${ }^{\circledR}$ ) on the in vitro control of phytopathogenic fungi isolates from papaya, as well as on the post-harvest quality of Tainung 1 papaya fruits.

\section{MATERIAL AND METHODS}

The in vitro experiment was conducted at the Universidade Federal Rural do Semiárido, in Mossoró, Rio Grande do Norte state, Brazil, from July to August 2015. The in vivo experiment was conducted in a packing house in the Flamengo farm, in Tibau, Rio Grande do Norte state, and Icapuí, Ceará state, both in Brazil, where the treatments were applied, followed by refrigerated storage at $10 \pm 2{ }^{\circ} \mathrm{C}$ and relative humidity of $90 \pm 5 \%$.

The pathogens used in the in vitro experiment were Alternaria sp., Colletotrichum gloeosporioides, Fusarium sp., Lasiodiplodia theobromae and Rhizopus sp., which were isolated from papaya fruits (Tainung 1 cultivar). The isolates were identified based on visual morphological characteristics in an optical microscope, using a dichotomic key (Barnett \& Hunter 1998). The clove essential oil used was obtained by hydrodistillation. The products used to control the pathogens were a biological fungicide based on Trichoderma harzianum conidia (Trichodermil $^{\circledR}, 48 \mathrm{~g} \mathrm{~L}^{-1}$ ), a resistance inducer based on copper phosphite $\left(2.0 \%\right.$ of $\mathrm{P}_{2} \mathrm{O}_{5}$ and $4.5 \%$ of $\left.\mathrm{Cu}\right)$ $\left(\mathrm{Cob}\right.$ Sistem $\left.^{\circledR}\right)$ and a chemical fungicide based on imazalil (Imazacure ${ }^{\circledR}, 500 \mathrm{~g} \mathrm{~L}^{-1}$ ). Among the tested products, only the Imazacure ${ }^{\circledR}$ fungicide is commonly used in treatments of fruits to prevent post-harvest diseases. The products were incorporated into a potato-dextrose-agar (PDA) culture medium, autoclaved at $120^{\circ} \mathrm{C}$ for $30 \mathrm{~min}$ (Nascimento et al. 2016). The rates used per liter of culture medium were $3 \mathrm{~mL}$ (clove essential oil), $6 \mathrm{~mL}$ (Trichodermil ${ }^{\circledR}$ ), $2 \mathrm{~mL}\left(\mathrm{Cob}\right.$ Sistem $\left.{ }^{\circledR}\right)$ and $2 \mathrm{~mL}\left(\right.$ Imazacure $\left.^{\circledR}\right)$. These rates were determined based on previous experiments, except for Imazacure ${ }^{\circledR}$, which was based on the manufacturer recommendation. Petri dishes with PDA culture medium without the products were used as a control.

After 7 days of growth, a 7-mm mycelial disk from the border of the fungal colonies from each fungal isolate was transferred to the center of the Petri dishes containing the PDA and the respective treatment.

These plates were kept in a BOD incubator at $26 \pm 2{ }^{\circ} \mathrm{C}$, for 5 or 7 days. Then, the mycelial growth of the fungi was measured with a ruler in diametrically opposite directions. The obtained values were used to calculate the percentage of inhibition of mycelial growth (IMG), using the formula IMG $=$ (control growth - treatment growth $\times 100$ )/ control growth (Bastos 1997).

The experiment was conducted in a complete randomized design, with 5 treatments (clove essential oil, Trichodermil ${ }^{\circledR}$, Cob Sistem ${ }^{\circledR}$, Imazacure ${ }^{\circledR}$ and a control), 5 fungal species (Alternaria sp., C. gloeosporioides, Fusarium sp., L. theobromae and Rhizopus sp.) and 5 replications. The means were compared by de Scott-Knott test at $5 \%$.

The fruits were harvested at the maturation stage (2-25\% of yellow peel surface surrounded by light green) and taken to the packing house, where they were selected, washed in water, disinfested with $1.5 \%$ sodium hypochlorite and weighed using a digital scale (Welmy BCW6). The treatments were applied with manual sprayers to the point of dripping. The solutions applied were prepared using distilled water for the control and dilutions with distilled water with clove essential oil $\left(3 \mathrm{mLL}^{-1}\right)$, Trichodermil ${ }^{\mathbb{R}}\left(6 \mathrm{~mL} \mathrm{~L}^{-1}\right)$ and Cob Sistem ${ }^{\circledR}\left(2 \mathrm{~mL} \mathrm{~L}^{-1}\right)$. Imazacure ${ }^{\circledR}$ was applied according to the manufacturer recommendation for post-harvest treatments of fruits, which consists in the immersion of the fruits in a solution of distilled water and Imazacure ${ }^{\circledR}\left(2 \mathrm{~mL} \mathrm{~L}^{-1}\right)$. All fruits were left to dry at room temperature $\left(25 \pm 2{ }^{\circ} \mathrm{C}\right.$, for $\left.30 \mathrm{~min}\right)$ and then immersed in a coating wax based on polyethylene and shellac $\left(\mathrm{Citrosol}^{\circledR}\right)$. Subsequently, the fruits were packed in plastic boxes and maintained in a cold room at $10 \pm 2{ }^{\circ} \mathrm{C}$ and $90 \%$ of relative humidity for 28 days. The evaluations were performed at $0,7,14$, 21 and 28 days of storage, plus two shelf life days at a temperature of $25 \pm 2{ }^{\circ} \mathrm{C}$. 
The experiment was conducted in a complete randomized design, with 5 treatments (clove essential oil, Trichodermil ${ }^{\circledR}$, Cob Sistem $^{\circledR}$, Imazacure $^{\circledR}$ and a control), 5 storage periods ( $0,7,14,21$ and 28 days) and 5 replications, with each replication consisting of 3 fruits.

The fruit external aspect was evaluated using a 1 to 5 visual scale, considering the presence of defects, namely, absence of injuries, spots, wilting and depressions (1); light (2), mild (3) and severe (4) presence of these problems; and extreme deterioration of the fruit (5) (Peixoto 2005). Fruits with grades higher than 3 were considered unfit for consumption. The fruit weight loss was evaluated by the difference between the initial and final weights and the severity of post-harvest diseases by using a 1 to 4 visual scale, considering the percentage of the fruit surface area that was affected: $0 \%(1)$, less than $10 \%(2)$, between $10 \%$ and $20 \%$ (3) and greater than $20 \%$ (4) (Peixoto 2005). The fruit pulp titratable acidity was evaluated according to the methodology described by the Instituto Adolfo Lutz (IAL 1985). The pulp was homogenized to determine its soluble solid contents using a digital refractometer (Biobrix ATC 104-D), and $\mathrm{pH}$ using a digital $\mathrm{pH}$ meter (Quimis).

The data were subjected to variance analysis, using the statistical software Assistat 7.7, and the means were compared by the Scott-Knott test at $5 \%$. The regression analysis was performed for the storage period factor.

\section{RESULTS AND DISCUSSION}

The alternative products used to control the pathogens affected significantly the mycelial growth of the evaluated fungi. The clove essential oil and
Trichodermil ${ }^{\circledR}$ were as efficient as the Imazacure $^{\circledR}$ chemical fungicide in inhibiting the mycelial growth of Alternaria sp., Colletotrichum gloeosporioides and Rhizopus sp. (Table 1).

The clove essential oil completely inhibited the L. theobromae and Rhizopus sp. growth (Table 1). Similarly, Combrinck et al. (2011) found a complete mycelial growth inhibition of $L$. theobromae isolates from avocado and mango, when using clove essential oil at rates of $2 \mathrm{~mL} \mathrm{~L}^{-1}$ and $3 \mathrm{~mL} \mathrm{~L}^{-1}$. The antifungal activity of the clove essential oil is attributed to the eugenol, which is one of its main compounds (Wang et al. 2010, Rana et al. 2011, Ascenção \& Mouchrek Filho 2013). According to previous studies, the use of clove essential oil causes the disorganization of cell contents, hyphae fragmentation, decreased turgidity and destabilization and rupture of the cell membrane in fungi (Wang et al. 2010, Costa et al. 2011).

Trichodermil ${ }^{\circledR}$ inhibited the growth of Alternaria sp. in $89 \%$, as well as the growth of C. gloeosporioides and Rhizopus sp. in $100 \%$ (Table 1). Lubaina \& Murugan (2015) evaluated the in vitro mycelial growth of Alternaria sesame using T. harzianum and found an inhibition rate of $96.7 \%$.

Cob Sistem ${ }^{\circledR}$ inhibited in $40 \%, 45 \%, 54 \%$ and $83 \%$ the mycelial growth of C. gloeosporioides, Alternaria sp., Fusarium sp. and L. theobromae, respectively, and had no effect on Rhizopus sp. (Table 1). Phosphites are used as resistance inducers to activate the plant defense mechanisms, and have a varied direct effect on pathogens (depending on the phytopathogen) and phosphite rate and type (Catão et al. 2013, Ogoshi et al. 2013, Alexandre et al. 2014).

The interaction between the factors evaluated was significant for the fruit external aspect, weight loss, $\mathrm{pH}$, titratable acidity and disease severity; and

Table 1. Mycelial growth inhibition of pathogens isolated from papaya fruits (Tainung 1 cultivar), using Imazacure ${ }^{\circledR}$, clove essential oil, Trichodermil ${ }^{\circledR}$ and Cob Sistem ${ }^{\circledR}$.

\begin{tabular}{|c|c|c|c|c|c|c|c|c|}
\hline \multirow{3}{*}{ Pathogen } & \multicolumn{8}{|c|}{ Treatment* } \\
\hline & \multicolumn{2}{|c|}{ Imazacure $^{\circledR}$} & \multicolumn{2}{|c|}{ Clove essential oil } & \multicolumn{2}{|c|}{ Trichodermil $^{\circledR}$} & \multicolumn{2}{|c|}{ Cob Sistem $^{\circledR}$} \\
\hline & $\% * *$ & $\operatorname{asen} \sqrt{ }(\mathrm{x} / 100)$ & $\%$ & $\operatorname{asen} \sqrt{ }(\mathrm{x} / 100)$ & $\%$ & $\operatorname{asen} \sqrt{ }(\mathrm{x} / 100)$ & $\%$ & $\operatorname{asen} \sqrt{ }(\mathrm{x} / 100)$ \\
\hline Alternaria sp. & 100 & $90 \mathrm{aA}$ & 73 & $68 \mathrm{bA}$ & 89 & $80 \mathrm{aA}$ & 45 & $42 \mathrm{bB}$ \\
\hline Colletotrichum gloeosporioides & 100 & $90 \mathrm{aA}$ & 87 & $79 \mathrm{bA}$ & 100 & $90 \mathrm{aA}$ & 40 & $39 \mathrm{bB}$ \\
\hline Fusarium sp. & 100 & $90 \mathrm{aA}$ & 80 & $72 \mathrm{bB}$ & 80 & $72 \mathrm{bB}$ & 54 & $50 \mathrm{bC}$ \\
\hline Lasiodiplodia theobromae & 100 & $90 \mathrm{aA}$ & 100 & $90 \mathrm{aA}$ & 84 & $67 \mathrm{bB}$ & 83 & $66 \mathrm{aB}$ \\
\hline Rhizopus sp. & 100 & $90 \mathrm{aA}$ & 100 & $90 \mathrm{aA}$ & 100 & $90 \mathrm{aA}$ & 0 & $0.0 \mathrm{cB}$ \\
\hline
\end{tabular}

*Averages followed by the same lowercase letters in the columns and capital letters in the rows do not differ statistically from one another by the Scott-Knott test at $1 \%$; ** percentage of mycelial growth inhibition. 
the storage period factor had an independent effect on the total soluble solid contents.

The external aspect of the fruits decreased during the storage period in all the treatments (Figure 1).

This decrease is normal during the storage period, due to the fruit senescence process. However, the treatments tended to reduce it. This result was already found by other authors working with papaya, regardless of the treatments applied (Rocha et al. 2005, Fernandes et al. 2010). Fruits treated with Imazacure ${ }^{\circledR}$, clove essential oil and Cob Sistem ${ }^{\circledR}$ were statistically different from the control. Imazacure ${ }^{\circledR}$ was the best treatment at 28 days of storage, differing significantly from the others. However, fruits treated with clove essential oil and Cob Sistem ${ }^{\circledR}$ had grades lower than 3 , indicating that these fruits were within the acceptable standards for trading.

The post-harvest diseases increased with the storage time. This is normal, due to the fruits natural senescence and loss of resistance along the ripening period (Figure 2).

However, fruits treated with Trichodermil ${ }^{\mathbb{B}}$, Cob Sistem ${ }^{\circledR}$, clove essential oil and Imazacure ${ }^{\circledR}$ showed a lower disease severity than the control fruits (Figure 2).

Fruits from all treatments presented postharvest diseases from 14 days of storage. The phytopathogens found in the injuries of the papaya fruits were Alternaria sp., C. gloeosporioides, Fusarium sp., Geotrichum sp. and L. theobromae. Regarding the pathogens control, the treated fruits differed significantly from the control fruits at 21 days of storage, and the fruits treated with clove essential

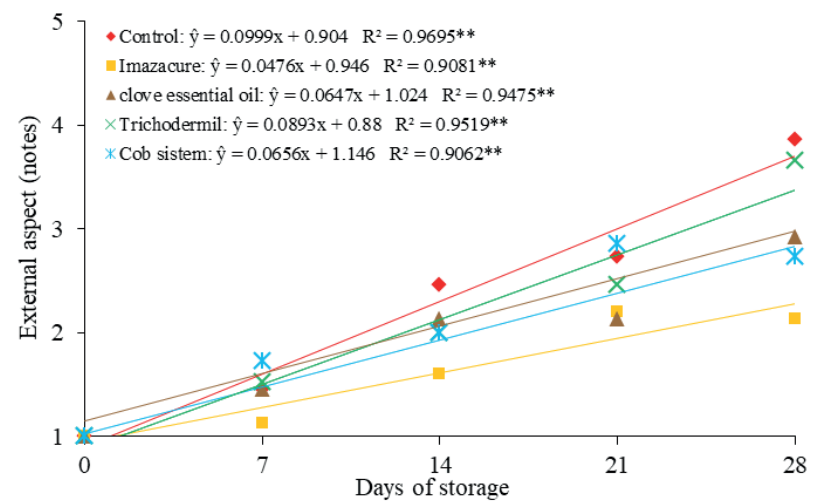

Figure 1. External aspect of the papaya fruits (Tainung 1 cultivar), using Imazacure ${ }^{\circledR}$, clove essential oil, Trichodermil ${ }^{\circledR}$ and Cob Sistem ${ }^{\circledR}$. oil, Trichodermil ${ }^{\circledR}$ and Imazacure ${ }^{\circledR}$ were statistically equal (Figure 2). T. harzianum (Trichodermil ${ }^{\circledR}$ ) has been reported as efficient in the control of diseases in different pathosystems. Its parasitism and production of secondary metabolites have been pointed out as the main mechanisms of action for this product (Lubaina \& Murugan 2015).

The fruit weight loss increased with increasing storage time (Figure 3).

The fruits treated with Imazacure ${ }^{\circledR}$, clove essential oil, Trichodermil ${ }^{\circledR}$ and Cob Sistem ${ }^{\circledR}$ had a similar weight loss at 14 days of storage, differing from the control (Figure 3 ).

Treated fruits and control fruits had a similar weight loss at 0,7 and 21 days of storage (Figure 3). The weight loss of the fruits treated with Imazacure ${ }^{\circledR}$, clove essential oil and Cob Sistem ${ }^{\circledR}$ were statistically similar at 28 days of storage.

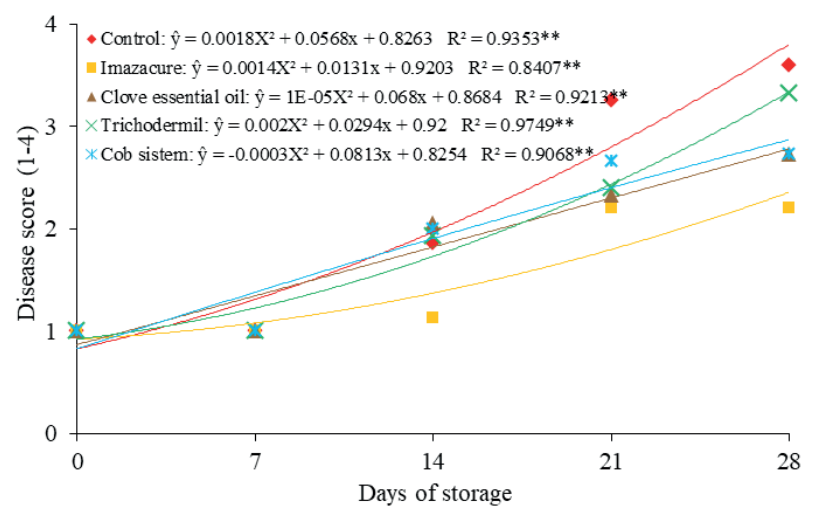

Figure 2. Severity of post-harvest diseases of the papaya fruits (Tainung 1 cultivar), using Imazacure ${ }^{\circledR}$, clove essential oil, Trichodermil $^{\circledR}$ and Cob Sistem ${ }^{\circledR}$.

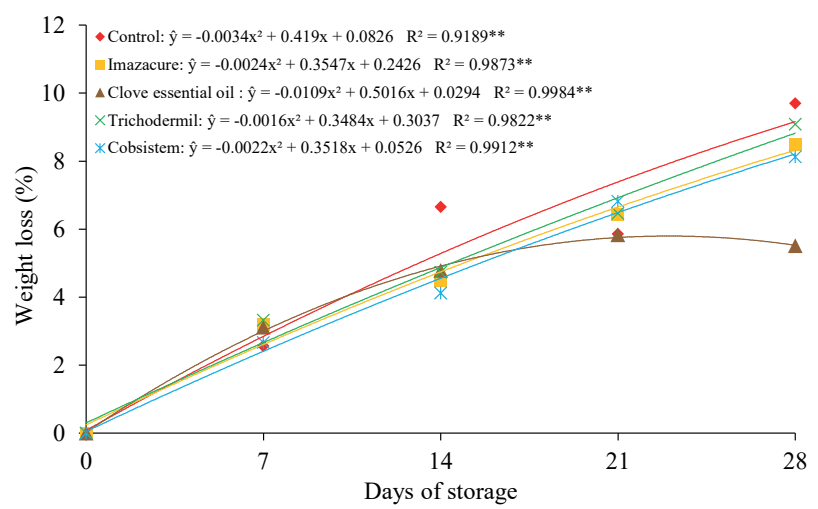

Figure 3. Weight loss of the papaya fruits (Tainung 1 cultivar), using Imazacure $^{\circledR}$, clove essential oil, Trichodermil ${ }^{\mathbb{R}}$ and Cob Sistem ${ }^{\circledR}$. 
The $\mathrm{pH}$ of the fruits varied during the storage times, regardless of the treatment applied (Figure 4).

These changes are common during ripening and are attributed mainly to the degradation and synthesis of organic acids (Almeida et al. 2006). Similarly, Pimentel et al. (2011) found variations for $\mathrm{pH}$ in papaya fruits (Hawai cultivar) during 6 days of storage, when subjected to treatments with cassava and potato starch. The $\mathrm{pH}$ of the fruits treated with Imazacure ${ }^{\circledR}(5.55)$, clove essential oil (5.58), Trichodermil ${ }^{\circledR}$ (5.54) and Cob Sistem ${ }^{\circledR}$ (5.51) were statistically equal at 28 days, but differed from that of the control, which had a $\mathrm{pH}$ of 5.64. Fagundes \& Yamanishi (2001) evaluated papaya fruits (Solo cultivar) and found a $\mathrm{pH}$ of 5.20 to 5.71, which are close to those found in the present study, denoting that the $\mathrm{pH}$ had no changes due to the applied treatments.

The titratable acidity varied during the storage periods (Figure 5).

According to Yamanishi et al. (2005), changes in this parameter are common due to maturation processes. Almeida et al. (2006) found a varied titratable acidity in papaya fruits of the Golden cultivar during the storage period.

The fruits treated with Imazacure ${ }^{\circledR}$, clove essential oil, Trichodermil ${ }^{\circledR}$ and Cob Sistem ${ }^{\circledR}$ had a higher titratable acidity than the control fruits at 7 days of storage (Figure 5). The fruits treated with Cob Sistem ${ }^{\circledR}$ had a higher titratable acidity than those fom the other treatments and the control fruits at 14 and 28 days of storage. The percentages of titratable acidity found in the present study were similar to those reported by Almeida et al. (2006), who found

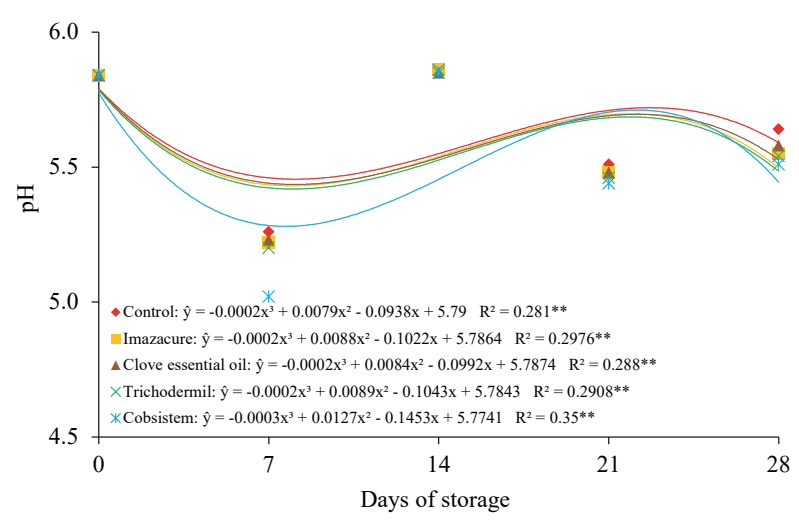

Figure 4. $\mathrm{pH}$ of the papaya fruits (Tainung 1 cultivar), using Imazacure $^{\circledR}$, clove essential oil, Trichodermil ${ }^{\circledR}$ and Cob Sistem ${ }^{\circledR}$.
$0.08-0.19 \%$ of citric acid in papaya fruits of the Golden cultivar.

The fruits had similar total soluble solid contents, regardless of the treatments. They decreased from 0 to 7 days of storage, but had a low variation from 7 to 28 days (Figure 6).

The increase for sugar content in papaya fruits is only observed while the fruits are attached to the plant (Ruggiero et al. 2011). Total soluble solid contents vary little after harvesting, since these fruits have a low starch content to be hydrolyzed (Jacomino et al. 2007). Similarly, Souza et al. (2014) found little variation in total soluble solid contents in papaya fruits of the Tainung 1 cultivar stored under $25{ }^{\circ} \mathrm{C}$ and $80 \%$ of relative humidity for 7 days; and Jacomino et al. (2007) found total soluble solid contents of 9.92-10.21 ${ }^{\circ}$ Brix in papaya fruits of the Golden cultivar.

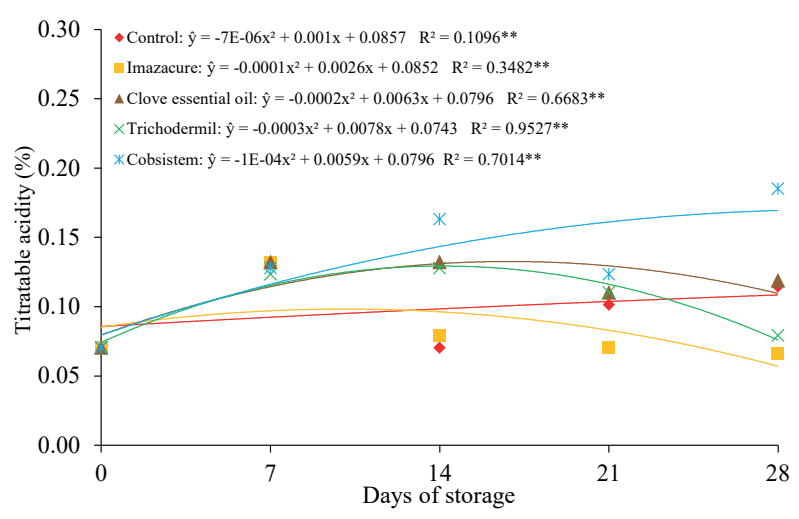

Figure 5. Titratable acidity of the papaya fruits (Tainung 1 cultivar), using Imazacure ${ }^{\circledR}$, clove essential oil, Trichodermil $^{\circledR}$ and Cob Sistem ${ }^{\circledR}$.

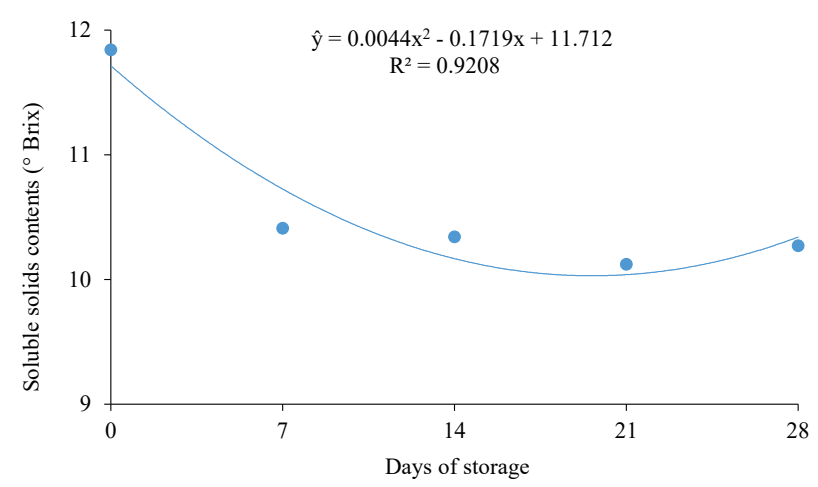

Figure 6. Total soluble solids contents of the papaya fruits (Tainung 1 cultivar), using Imazacure ${ }^{\circledR}$, clove essential oil, Trichodermil ${ }^{\circledR}$ and Cob Sistem ${ }^{\circledR}$. 


\section{CONCLUSIONS}

1. The clove essential oil and the Trichodermil ${ }^{\circledR}$ biological fungicide were as efficient as the Imazacure $^{\circledR}$ chemical fungicide in inhibiting the mycelial growth of Alternaria sp., Colletotrichum gloeosporioides and Rhizopus sp., in vitro;

2. The control of pathogens in the fruits treated with clove essential oil, Cob Sistem ${ }^{\circledR}$ and Imazacure ${ }^{\circledR}$ was similar up to 21 days of storage;

3. The alternative treatments do not alter the $\mathrm{pH}$, titratable acidity and soluble solids contents of papaya fruits of the Tainung 1 cultivar.

\section{REFERENCES}

ALEXANDRE, E. R. et al. Fosfito no manejo da antracnose do jiló. Pesquisa Agropecuária Brasileira, v. 49 , n. 12, p. 930-938, 2014.

ALMEIDA, R. F. et al. Influência da temperatura de refrigeração sobre as características químicas do mamão cv. 'Golden'. Ciência e Tecnologia de Alimentos, v. 26, n. 3, p. 577-581, 2006.

ASCENÇÃO, V. L.; MOUCHREK FILHO, V. E. Extração, caracterização química e atividade antifúngica de óleo essencial de Syzygium aromaticum (cravo-da-índia). Caderno de Pesquisa, v. 20, n. especial, p. 137-144, 2013.

BARNETT, H. L.; HUNTER, B. B. Illustrated genera of imperfect fungi. 4. ed. St. Paul: American Phytopathological Society Press, 1998.

BASTOS, C. N. Efeito do óleo de Piper aduncum sobre Crinipelise e outros fungos fitopatogênicos. Fitopatologia Brasileira, v. 22, n. 3, p. 441-443, 1997.

CATÃO, H. C. R. et al. Fungicides and alternative products in the mycelial growth and germination control of Alternaria tomatophila. Idesia, v. 31, n. 3, p. 21-28, 2013.

COMBRINCK, S. et al. In vitro activity of eighteen essential oils and some major components against common postharvest fungal pathogens of fruit. Industrial Crops and Products, v. 33, n. 1, p. 344-349, 2011.

COSTA, A. R. T. et al. Ação do óleo essencial de Syzygium aromaticum (L.) Merr. \& L. M. Perry sobre as hifas de alguns fungos fitopatogênicos. Revista Brasileira de Plantas Medicinais, v. 13, n. 2, p. 240-245, 2011.

DANTAS, S. A. F. et al. Indutores de resistência na proteção do mamão contra podridões pós-colheita. Summa Phytopathologica, v. 30, n. 3, p. 314-319, 2004.

FAGUNDES, G. R.; YAMANISHI, O. K. Características físicas e químicas de frutos de mamoeiro do grupo 'Solo' comercializados em 4 estabelecimentos de Brasília - DF. Revista Brasileira de Fruticultura, v. 23, n. 3, p. 541-545, 2001.

FERNANDES, P. L. O. et al. Qualidade de mamão 'Formosa' produzido no RN e armazenado sob atmosfera passiva. Revista Ciência Agronômica, v. 41, n. 4, p. 599604, 2010.

FOOD AND AGRICULTURE ORGANIZATION OF THE UNITED NATIONS (FAO). Produção mundial de frutas frescas. 2016. Available at: $<$ www.fao.org $>$. Access on: 06 Mar. 2018.

HAMINI-KADAR, N. et al. Antifungal activity of clove (Syzygium aromaticum L.) essential oil against phytopathogenic fungi of tomato (Solanum lycopersicum L.) in Algeria. Journal of Experimental Biology and Agricultural Sciences, v. 2, n. 5, p. 447-454, 2014.

INSTITUTO ADOLFO LUTZ (IAL). Normas analiticas, métodos químicos e físicos para análise de alimentos. 3. ed. São Paulo: Instituto Adolfo Lutz, 1985.

JACOMINO, A. P. et al. Influência do intervalo entre a colheita e a aplicação do 1-Metilciclopropeno no controle do amadurecimento de mamão. Revista Brasileira de Fruticultura, v. 29, n. 3, p. 456-459, 2007.

LUBAINA, A. S.; MURUGAN, K. Evaluation of biological efficacy of Trichoderma species isolates against Alternaria leaf spot disease of sesame. International Journal of Applied Biology and Pharmaceutical Technology, v. 6, n. 1, p. 17-24, 2015.

NASCIMENTO, S. R. C. et al. Sobrevivência de estrutura de resistência de Macrophomina phaseolina e Sclerotium rolfsii em solo tratado biologicamente. Revista Agro@mbiente,v. 10,n. 1, p. 50-56, 2016.

OGOSHI, C. et al. Potassium phosphite: a promising product in the management of diseases caused by Colletotrichum gloeosporioides in coffee plants. Bioscience Journal, v. 29, supl., p. 1558-1565, 2013.

PEIXOTO,A. M. S. Controle de patógenos e prolongamento da vida útil pós-colheita do mamão formosa 'Tainung 01' através do controle biológico e químico. 2005. 71 f. Dissertação (Mestrado em Fitotecnia) - Universidade Federal Rural do Semiárido, Mossoró, 2005.

PIMENTEL, J. D. R. et al. Estudo da conservação de mamão 'Havaí' utilizando películas comestíveis a diferentes temperaturas. Scientia Plena, v. 7, n. 10, p. 1-6, 2011.

RANA, I. S. et al. Evaluation of antifungical activity in essential oil of the Syzygium aromaticum (L.) by extraction, purification and analysis of its main component eugenol. Brazilian Journal of Microbiology, v. 42, n. 4, p. 1269-1277, 2011. 
REZENDE, J. A. M.; FANCELli, M. Doenças do mamoeiro (Carica papaya L.). In.: KIMATI, H. et al. (Eds.). Manual de fitopatologia: doenças das plantas cultivadas. São Paulo: Agronômica Ceres, 1997. p. 452465.

ROCHA, R. H. C. et al. Qualidade pós-colheita do mamão formosa armazenado sob refrigeração. Revista Brasileira de Fruticultura, v. 27, n. 3, p. 386-389, 2005.

RUGGIERO, C. et al. Mamão, uma história de sucesso. Revista Brasileira de Fruticultura, volume especial, p. 76-82, 2011.

SOUZA, A. F. et al. Fisiologia do amadurecimento de mamões de variedades comercializadas no Brasil. Revista Brasileira de Fruticultura, v. 36, n. 2, p. 318328, 2014.
SUÁREZ-QUIROZ, M. L. et al. Aislamiento, identificación y sensibilidade a antifúngicos de hongos fitopatógenos de papaya cv. Maradol (Carica papaya L.). Revista Iberoamericana de Tecnologia Postcosecha, v. 14, n. 2, p. 115-124, 2013.

VALENZUELA, N. L. et al. Biological control of anthracnose by postharvest application of Trichoderma spp. on Maradol papaya fruit. Biological Control, v. 91, n. 12, p. 88-93, 2015.

WANG, C. et al. Antifungal activity of eugenol against Botrytis cinerea. Tropical Plant Pathology, v. 35, n. 3, p. 137-143, 2010.

YAMANISHI, O. K. et al. Comportamento da maturação de mamão Tainung 01 cultivado em Brasília. Revista Brasileira de Fruticultura, v. 27, n. 2, p. 314-316, 2005. 